\title{
Rule of Law and the Doctrine of Proportionality; Appraisal, Rational and Validation
}

\author{
* Hidayat Ur Rehman, Assistant Professor \\ ** Dr. Syed Raza Shah Gilani, Assistant Professor (Corresponding Author) \\ *** Dr. Ilyas Khan, Assistant Professor
}

\begin{abstract}
In Germany, many researchers - including judges - believe that the idea of proportionality should stem from the notion of Rechsstaat. The term, when translated into English, is Rule of Law, and "Etat de Droit" in French. Applying the rule of law as a reason for adopting proportionality as a factor for limiting constitutional rights via the constitutionality of sub-constitutional law has also been implemented by other legal organizations. To understand the liaison connecting the rule of law and the doctrine of proportionality, it is essential to determine whether the proportionality could have a harmony with the values of rule of law in five steps. First, it is necessary to enquire whether the rule of law principle has a constitutional position. Next, it must be determined whether the rule of law as a principle of the constitution includes a feature of Human Rights. Third, we must ascertain whether the rule of law, as a principle of the constitution, is based upon an equilibrium amid constitutional rights and their limitations. Fourth, it must be determined that such a balance is conducted through the use of limitation clauses (statutes or the common law). Fifth, it is essential to establish an opinion on whether limitation clauses, which advance the standard of the rule of law, are based on proportionality.
\end{abstract}

Keywords: Doctrine of Proportionality, Rule of Law, principle of Balance, Limitation Clauses Introduction

The rule of law principle has a central role in the laws of most democracies. It has a constitutional status in those cases where the constitution itself declares that explicitly. Several constitutions affirm the superiority of the rule of law. For instance, the Portuguese Constitution (1976) ordains clearly that the Portuguese Republic is a state based on democracy and the rule of law (Constitution of Portugal, Art. 2). Similarly, the Spanish constitution (1978) declares Spain to be a social state based on democracy, subject to the rule of law (Constitution of Spain, Art. 1(1)).

First Assumption: "The Rule of Law has a constitutional status"

The legal systems which refer to the rule of law in their constitution, are considered not merely of declaratory nature but as having constitutional operative effect. However, in those cases where the constitution is silent, then more responsibility comes on the shoulders of the judiciary. For example, here I must state that the Constitutional Court of Germany has recognized the principle of "the rule of law" (Rechtsstaat) as having constitutional status. The court arrived at this conclusion after reading the articles of the fundamental law as one whole text, (Donald P Kommers\& Miller, 2012) p 179.) while paying attention to Germany's democratic nature.

\section{Second Assumption: "The Rule of Law Includes Human Rights"}

Similar to the concept of democracy, the concept of the rule of law has several meanings. Its content may change following the users' tradition. All agree that the principle contains both formal aspects (the "formal rule of law") and jurisprudential aspects (the "jurisprudential rule of law"). Both aspects define the principle of legality. According to both aspects, the "rule of law" is "the law of rules". A. Scalia, (1989) This assertion immediately raises the difficult question of whether Hitler's Germany, or Apartheid South Africa, were legal systems according to the "rule of law". Obviously, the answer is in the negative, but is not very easy to deliver. This is the most controversial branch of the rule of law. However, all of them concur to the extent that the rule of law recognizes and protects human rights.

Here, it is needed to be aware of the substantive aspects of the rule of law. Presidential pardon is a substantive side, but it must as per the constitutional provisions. A law in conflict with the

\footnotetext{
* Department of Law, Abdul Wali Khan University Mardan, Pakistan. Email: hidayat@awkum.edu.pk

** Department of Law, Abdul Wali Khan University Mardan, Pakistan. Email: sgilani@awkum.edu.pk

*** Department of Law, Abdul Wali Khan University Mardan, Pakistan. Email: drilyas@awkum.edu.pk
} 
constitution is void, and the courts are authorized to declare it as such. Similarly, judicial review on the constitutionality of the Act, therefore, also derives from the substantive aspect of the rule of law principle. The constitutional grounds for judicial review of actions by the administration may also derive from the substantive aspect of the rule of law. Moreover, if the executive branch violates its obligations under the constitution, or under statute, the victims of such violations may be entitled to a remedy even if the executive action was carried out without fault (without negligence or intent). Finally, and above all, its substantive aspect strives to ensure several justice-related values: primarily to recognize and protect human rights. (Karpen, 2009) The rule of law is not merely the law of rules; the Indian Supreme Court premised the concept of judicial review on its foundation and ruled that it means the rule of liberty (Jain, 2003). After going through all this discourse it can be said that the rule of law is the best tool to achieve the aim, if the aim is the supremacy of law, which will also achieve the goal of protecting the basic rights of the people. It can only be achieved if the courts with this aim interlink Rule of Law and Human Rights of the people. The Judiciary has to evolve now and make such a strategy that could not only force the government to abide by the law but also create conditions where people could develop the ability to enjoy their rights in an appropriate and meaningful way (Cohen-Eliya; Porat, 2014).

Third Assumption: "the rule of law is based on a balance between constitutional rights and public interest"

The substantive aspect of the "rule of law", much like the substantive aspect of democracy, is not made up entirely of the protection of constitutional rights. (Habermas, 2015) Rather, the "rule of law" principle is a result of an appropriate balance between all its aspects. This is the prevailing view to date across contemporary constitutional democracies. (Habermas, 2015) Justice Khanna, an Indian Supreme Court Judge, stated that:

The rule of law in all civilized societies is now the agreed standard. It is associated with the independence of the citizen everywhere. It aims to establish a balance between the opposite principle of individual rights and public order. (A.D.M Jabalpur, 1976).

Hence, when the constitutional rights are relative, both the right and the license to limit it are found in the constitution. About this, it can be argued that collective interests and rights both can be the subject matter of principles provided that the interests which they protect are realized to the greater possible extent given factual and legal possibilities i.e. Alexy denoted that a significant characteristic of the balancing model for the rule of law is that it considers rights as commensurate with each other and the public interest. It implies that the significance of the safeguard of rights and the protection of the public interest can be measured, compared, and balanced on a single scale. (Craig, 2010)

Fourth Assumption: "The balance is carried out by limitation clauses"

The key concept of the "constitutional democracy is balancing, the balancing between the formal and substantive aspects of democracy". (Karpen, 1999) Such balancing presupposes the simultaneous coexistence of both aspects while determining the proper relationship between them. That balancing reflects the relative social value of each competing aspect when considered in proper context. (Gardbaum, 2010) Chief Justice Dicksons' words (Oake, 1986) were taken into consideration at the time of drafting the general limitation clause appearing in article 36(1) of the South African Constitution, which provides that:

The rights provided by the Bill of Rights can be constrained from the viewpoint of universal application of law only according to a reasonable and justified commitment to a free and democratic society founded on human dignity, freedom, and equality.

Hence, when the relevant context is the tension between the formal facet of democracy and constitutional rights, that balancing is resolved through the use of limitation clauses (either general or specific, express or implied), which determine the required conditions under which a subconstitutional law may limit a constitutional right.

\section{Fifth Assumption: "limitation clauses are founded on proportionality"}

Generally, the contents of limitation clauses properly balance the various facets of the rule of law. Hence, the sub-constitutional law limiting the constitutional right should be proportional. In a more specific sense, proportionality may be derived immediately from the principle of the rule of law, as we know that in both formal and substantive aspects it is in a state of constant tension. (Mhone \& Edigheji, 2003) The doctrine of proportionality is a solid and concrete solution for this tension to 
strike balance, as it recognizes both formal and substantive aspects while balancing both proportionally. Such a balance would have to recognize, on the one hand, the need to realize the will of the majority as expressed by the legislative body, and on the other, the proportional limitations on such power by the majority. Such an approach was adopted in Germany by constitutional commentators and the courts. According to this approach, proportionality is derived from the rule of law. (Donald Kommers, 2006) It can be justified that democracy is the source of proportionality, which applies mutatis mutandis to the principle of rule of law, as a legal source of proportionality. Hence, the close connection between rule of law and democracy makes this principle a special source of proportionality. (Rehman, 2021)

\section{Difference between "Formal and Substantive Concepts of the Rule of Law"}

It is very significant to analyze the substantive and formal understandings or notions of the rule of law. Its theoretical formation can be divided into two basic categories, known as the "formal" and the "substantial" version, which has three separate forms. These alternative formulations run from thinner to thicker accounts, meaning that they move from formulations with fewer requisites to those with more requisites. It is essential in legal theory to separate the rule of law conception into formal and substantive branches. As wicks denoted that:

The formal concepts of the rule of law focused on how the law was created (was it properly adopted by a competent person, etc.). Explain the following principle (was it clear enough to guide a person's behavior to enable him to live, etc.). And the temporary dimension of the aging test (whether it was expected or retreated, etc.). However, the formal notion of the rule of law does not ask to judge the definite content of the legislation itself. It does not care if the law is a good one or a bad one in that respect, provided that the formal rules of law itself are fulfilled. (Wicks, E. (2003)

Hence it means that those who support the substantive concepts of the rule of law search to go beyond that. They agree that it has the formal qualities discussed earlier; however, they want to take the principle furthermore (Basic, 2017). Rule of law is considered to be the basis or fountain of some substantive rights. The notion is utilized as the basis for those rights, which are then used to differentiate between good laws consistent with those rights and poor laws that do not comply with those rights (Craig, 2017).

Alternative Rule of Law Formulations

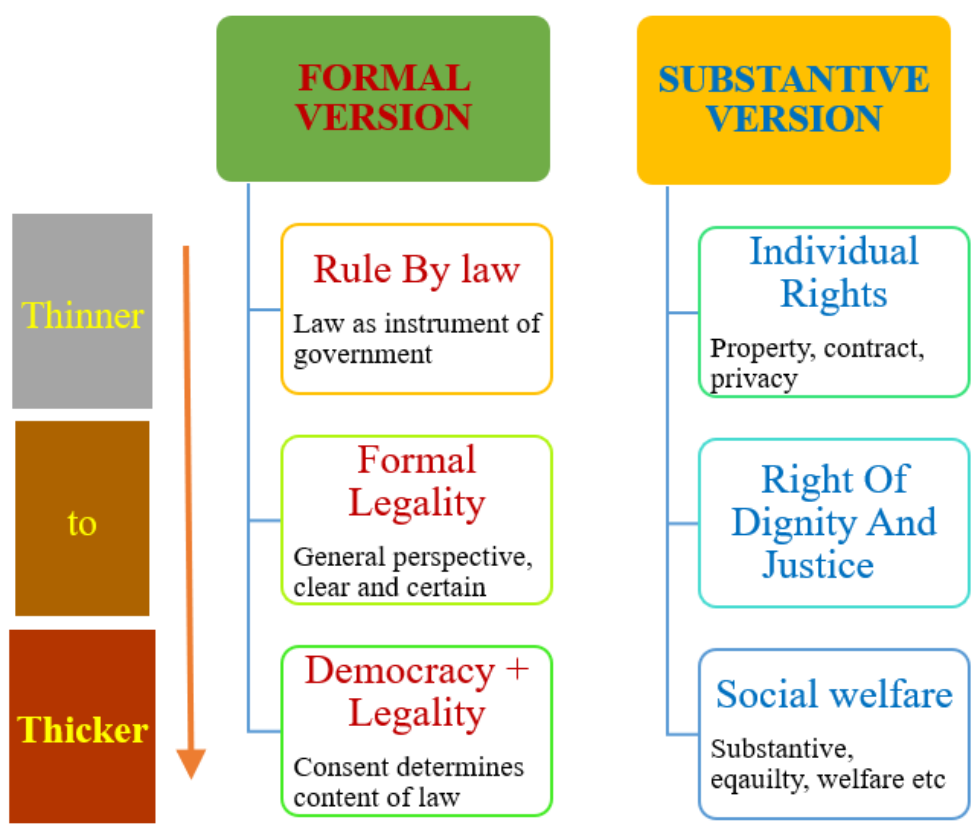

Figure 1

Hence we can conceive that the proper sources are focused on formal theories, while substantive theories focus on the requirements about the concept of the law (must cooperate with principles of morality or justice). This difference should not be taken strictly, because the formal versions incorporate the substantive requirements. 


\section{Rule of Law: Formal version}

This is its thinnest formal form, which means that law is the way by which any state runs its business, so that anything the government does, it must be done through law (Reynolds, 1989). In this fashion, the rule of law does not have any because it collapses into the notion of government rule. (Reynolds, 1989) This can be further elaborated to mean that means that any government action must be permitted by law. (Neumann, 2014) Hence, rule of law is a significant feature of every modern state in this narrow sense. The formal rule of law believes that, for there to be a government under the law, the law must comply with certain procedural requirements. This view does not say anything about the morals of the law, but rather that the subjects should be guided in such a way that everyone knows their position in the state (Sweet, A.; Mathews, J. (2008). Therefore, to obtain the required certainty, this structured type of rule of law should be prospective, simple, adjudicated by an impartial judiciary, and must give the people access to the courts. Formal Legality is another main trait of the formal kind of rule of law which means that the law needs to be forward-looking, general, transparent, and reasonably stable, (Raz, 2017) which means that the law should be autonomous and public, and fair hearings and their consequences should be conducted by the courts without any prejudice, except for two points: how should the need for equality be interpreted and if the rule of law itself is a moral good? (Raz, 2017).

As stated by Moller the next and final account of the rule of law is democracy and formal legality, thus adding democracy to formal legality. (Møller \& Skaaning, 2012) In this mode, democracy is silent as it does not describe what the elements of law need to be. It is a procedure assessment that provides how-to ascertain the elements of law, which can be further elaborated to show that freedom means living under the law of one's own choice. This is the concept of liberty in civil and political life. According to Jurgen, only from the principle of self-determination can the new legal order derive its legitimacy; individuals should always be in a position to comprehend themselves as makers of the law to which they are subject as addresses (Rehg \& Bohman, 1996). Law obtained its force from the will of the people. Judges, government functionaries, and people should still obey and enforce the legislation as passed by individuals (chosen legislature). According to that interpretation, formal legality, particularly in its requisites of certainty and impartiality of appliance, derives its weight from democracy and serves it (Rehg \& Bohman, 1996). This feature of the rule of law is parallel and very much in accord with the philosophy of democracy and the doctrine of proportionality, as they also contain the features of certainty and equality.

\section{Rule of Law: Substantive version}

Rule of law is included in all the substantive versions. The elements of formal rule of law are included in all substantive versions of the rule of law; it then goes further. In the substantive version, human rights are included in it. According to Ronald, the notion of 'rights' implies that individuals have moral rights and responsibilities to each other and civil rights vis-a-vis the state as a whole. It requires that these moral and civil rights be acknowledged by affirmative legislation so that they can be implemented by courts or other judicial structures of the familiar sort upon the request of individual people (Dworkin, 1979). The substantive rule of law requires legislation to be in conformity with the principles of equality, to preserve basic rights, to be consistent with the principles of procedural fairness and natural justice, and to comply with international law obligations (Singer, J. M. 2012). The substantive rule of law is weakened both by reducing the protection of civil liberties and by reducing the jurisdiction and responsibility of those exercising power in such a way that civil liberties and human rights are eroded (Alexy, 2014). It is pertinent to mention here that a more substantive comprehension of the rule of law is more controversial because the content of rights is more contested than its formal version: what are the different ways in which proportionality can be related to i.e. the formal rule of law and ii. the substantive rule of law. The principle of legality does not simply illustrate how principles derived from its practical theories are upheld but is itself considered to be a way of promoting the rule of law (Alexy, 2014).

The rule of law in a substantive sense also safeguards the right to dignity and justice. In other words, it means that anti-democratic implications of rights. It is pertinent to mention here that individual rights have hostile implications for democracy. Western liberal democracies have been struggling to find an equilibrium. This struggle is dominated by the conflict over rule of law. (Alexy, 2014) There are two interconnected but discernible aspects to this: the boundaries put on democracy and the authority, and according to the judges. The rule of law is more concerned with human rights 
than democratic government and is more committed to it. (Hutchinson, 1987). Democracy still governs, it could be stated, while human rights are expressly included in constitutions or bills of rights that are popularly enacted, since those provisions are the creations of democratic powers themselves (Hutchinson, 1987).

On the question that, the structure will no longer be the rule of law, but the rule of the men and women who are judges, if judges consulted their perceptions to fill in the rights' content (Tamanaha, 2004), Dworkin negated that judges should consult their interpretations of the core values, but should instead aim to locate the underlying or evolving ideals of the society within the complexity of legal rules (Reynolds, 1989). The last version of the substantive rule of law is social welfare; democracy and individual rights. Allan once argued that the rule of law is a blend of aspirations, norms, and standards: it incorporates conventional principles of individual natural justice and liberty, and, more broadly, concepts of the conditions of justice and equality in governmentgoverned relations. (Tamanaha, 2004) Hence, legality is its main perception. Formal legality, human rights, and democracy are embedded in the thickest substantive versions of the rule of law but introduce an additional qualitative aspect that could be loosely classified under the social welfare rights mark (Moller, 2012). It needs to be mentioned that rule of law cannot be tied with everything good that individuals demand from the government. The urge to always read it this way is testimony of the symbolic value of the rule of law, but it should not be distorted. The main concern of its substantive aspect is the contents of law; this differentiation between the formal and substantive theories of the rule of law is broadly known. Therefore, we have to examine the degree to which UK law upholds basic human rights and civil liberties when deciding if the UK constitution adheres to the principles of substantive description of the rule of law. Its formal theories emphasize not the substance of the law, but on how the law is made. For example, it requires the law to be simple, prospective rather than retrospective, capable of being followed and accessible to all persons in the same way. Formal theories examine the way the law is effective at its role governing, setting no conditions as to the contents of the legislation passed. (Craig, 1997).

As such, there is criticism as to their significance, that it is possible to hold on to the standards of formal theories of the rule of law in a legal system whose rules actively violate human rights and civil liberties (Dyzenhaus, 1989). It is generally agreed that the formal rule of law is a necessary minimum. On the other hand, substantive versions of the rule of law are questioned for being lacking in substance. Fundamental rights are secured by its substantive concept if those that promote fundamental rights and civil liberties are the principles required by the rule of law for the substance of the law. The concepts underpinning the substantive theory of the rule of law are more relevant than the rule of law itself (Raz, 1977), and these are also the main objective of democracy, and eventually the philosophy of the common law system.

\section{Proportionality and Interpretation}

Democracy, the rule of law, and legal principles (or principle theory) are not the only possible sources upon which to establish proportionality. Another very important source is the constitution itself and its interpretation. (Pulido, 2013) This view has been adopted by several legal systems, in which Germany, Canada, Spain, and Israel are prominent. Constitutional interpretation approaches the text generously (R. v. Big M Drug Mart [1985]). It aspires to achieve constitutional harmony. It adopts a holistic view of the constitution, and different parts of the constitution are deemed interconnected. (Donald P Kommers \& Miller, 2012) Together, they establish constitutional unity based on fundamental values which inspire the interpretation of the constitutional text and create an objective hierarchy of values. (Friauf, 1968) According to this hierarchical order, constitutional rights constitute the objective values upon which the constitution is built. These objective values, and the values that limit them, are a vital characteristic of the objective constitutional structure. (Grimm, 2005) As the Constitutional Court in Germany observed in Luth: The Basic Law is not a document that is value-neutral... The section of Basic Rights provides an objective order of values which enhances the efficient power of fundamental rights strongly (Donald P Kommers\& Miller, 2012).

The different values that together constitute the objective constitutional order tend to conflict with one another. For each principle, it may be possible to find an opposing principle. (Alexander \& Kress, 1996) Conflict resolution is found by forming a synthesis between the different principles and creating internal harmony between them. All these may be achieved by using the concept of proportionality, which helps to maintain the unity of the constitution. The interpretive approach views 
proportionality as part of the constitution because of the interpretation of the entire constitution. At times, proportionality may be derived directly from the explicit text of the constitution. At other times, it may be derived from its implicit text. In both cases, however, we are dealing with a constitutional level doctrine that stems from the desire to ensure constitutional unity and harmony. (Beatty, 2004) The operative effect of proportionality, as mentioned, is not at the constitutional level but only at the sub-constitutional level. This kind of effect may determine the constitutionality of subconstitutional law trying to limit a constitutional right.

Hence, constitutional proportionality determines the legislative validity or compatibility of a sub-constitutional law (a statute or a common-law) that limits a constitutional right. It does so while fully developing the concept of proportionality and its components. On the other hand, interpretive balance deals not with the question of validity, but also with that of meaning. It provides meaning to the text of the legal norm. The balance it carries out uses, by analogy, only one of the components used by proportionality: that of proportionality stricto-sensu. Democracy, the "rule of law", the Principle theory, and constitutional interpretation are all legal sources from which proportionality may be derived as a constitutional concept. When the conflicting principles are of constitutional status and a query is raised as to the legal validity of the limiting sub-constitutional law, each of those four sources, and all four of them combined, can establish the constitutional status of proportionality. (Alexy, 2009)

\section{Doctrine of Proportionality and protection of the Freedom of Expression.}

In the UK, previous to the Human Rights Act of 1998, the right to free speech did not exist, but, in a detrimental sense, freedom of speech was subject to the limits imposed by legislation (Barak, 2016). Article 10 of the European Convention on Human Rights governs the Freedom of expression, which is integrated into domestic law under the 1998 Human Rights Act. Though, this right is restricted by limitations. Under Article 10, Freedom of expression requires freedom of opinion, right to use information and ideas, without the interference of public officials (Human Rights Act 1998, Article 10). Lawful constraints on the right are further permitted regarding members of the legal profession, the armed forces, and constabularies. The right is subject to the legal limits required in a society based on democracy for state security or public security to prevent the crime or disorder, to protect one's health or moral values, or for the protection of the rights and freedoms of others ( $\mathrm{R} v$ Sherwood ex parte telegraph Group Plc 2002). The result of Article 10 remains that all constraints on the right need to be warranted in conjunction with other limited articles; furthermore, they must be proportionate and necessary (Slapper \& Kelly, 2011) conditions. The main difference between the range and expression of the constitutional right is recognized by Article 10(1) of the ECHR. It says that everybody is entitled to freedom of speech. Freedom to express views and to obtain and impart knowledge and ideas shall be included in the right, without intervention by public authorities and regardless of boundaries. This Article shall not prohibit States to require radio, television, or cinema licenses to be approved.

Therefore, Article 10(1) is accountable for producing the range of the right to autonomy of expression. As illustrated by its interpretation, the range it entails is extremely diverse and covers a range of forms (verbal, written, advertisements) plus content (including racist hate speech, libel, or obscenity) (Ovey \& White, 2003). Despite this great diversity, the convention retains a clause that enables restriction of the freedoms used. The application of this freedom, since it entails accountabilities and obligations, may be held to certain constraints, formalities, provisions, or penalties as issued by the legal system which stems from a democratic civilization. These conditions are in the general interest of protecting society's ethics, national safety, and the right of people's confidential information, and ensuring an unbiased and commanding judiciary. Thus, as stated by the article, the "right to freedom of expression" is subject to constraints by law for the general safeguard of people's rights, preventing the occurrence of hate crime or restricting pornographic communication. (A, 2012) The restrictions are fundamental in a democratic society or to put it simply, must be proportional. (A, 2012)

\section{Conclusion}

This article also argued that the doctrine of Proportionality has a direct connection with human rights theories. It is a vessel for these theories. There are many theories regarding human rights and their limitations. Most of them can be found in the doctrine of proportionality. Proportionality is an analytical and a legal tool and is fed by external data. Its aim is the protection of both the rights of 
individuals and public interest simultaneously. It must be said that this doctrine is highly compatible with most human rights theories: for example, Alexy's theory of principle-shaped rights, which describes that a principle always strives for the best possible realization. It can also be concluded that proportionality gains not only the legal source for its constitutional status but also a substantive justification for its operation. If proportionality derives from democracy and the rule of law, then both can serve as justifications for proportionality. Indeed, human rights, democracy, and the rule of law are inseparable. The liaison between democracy, human rights, and the rule of law is founded on the understanding that when several legal conditions are met, the restrictions on human rights are not undemocratic. In other words, it can be said that a suitable equilibrium between the rights of individuals on one side and the reason for the restriction on others are struck down. A variety of reasons can also justify the significance of proportionality to a new context, leading to the debate on the freedom of expression and its safeguard in the framework of the doctrine of proportionality.

\section{Bibliography}

A, B. (2012). Proportionality: Constitutional Rights and Their Limitations Cambridge University Press.

Alexander, L., \& Kress, K. (1996). Against legal principles. Iowa L. Rev., 82, 739.

Alexy, R. (2009). A theory of constitutional rights: Oxford University Press, USA.

Barak, A. (2016). the Judge in a Democracy Princeton University Press.

Beatty, D. M. (2004). The ultimate rule of law: Oxford University Press, USA.

Cohen-Eliya, M., \& Porat, I. (2011). Proportionality and the Culture of Justification. The American Journal of Comparative Law, 59(2), 463-490.

Collingsworth, T. (2002). The key human rights challenge: Developing enforcement mechanisms. Harv. Hum. Rts. J., 15, 183.

Comella, V. F. (2014). Constitutional courts and democratic values: a European perspective: Yale University Press.

Craig, P. (1999). Unreasonableness and proportionality in UK law: na.

Craig, P. (2017). Formal and substantive conceptions of the rule of law: an analytical framework. In The Rule of Law and the Separation of Powers (pp. 95-115): Routledge.

Den Otter, R. C. (2009). Judicial review in an age of moral pluralism: Cambridge University Press.

Dobner, P., \& Loughlin, M. (2010). The twilight of constitutionalism? : Oxford University Press.

Dworkin, R. (1979). POLITICAL JUDGES AND THE RULE OF-LAW.

Dyzenhaus, D. (1998). Law as justification: Etienne Mureinik's conception of legal culture. South African Journal on Human Rights, 14(1), 11-37.

Dyzenhaus, D. L. (1989). Hard'casesin'wicked'legal systems. University of Oxford,

Fordham, M. (2002). Common law proportionality. Judicial Review, 7(2), 110-123.

Fordham, M., \& de la Mare, T. (2001). Identifying the Principle of Proportionality In: Jowell. Understanding Human Rights Principles, Oxford and Portland: Hart Publishing, 55-59.

Friauf, K. H. (1968). Techniques for the Interpretation of Constitutions in German Law. Paper presented at the Proceedings of the Fifth International Symposium on Comparative Law.

Gardbaum, S. (2010). A Democratic Defense of Constitutional Balancing. Law \& Ethics of Human Rights, 4(1), 79-106.

Gargarella, R. (2005). Theories of democracy, the judiciary, and social rights.

Gotz, V. (1991). Legislative and Executive Power under the Constitutional Requirements entailed in the Principle of the Rule of Law. New Challenges to the German Basic Law, Baden-Baden: Nomos Verlagsgesellschaft.

Grimm, D. (2005). The Protective Function of the State, Georg Nolte, European and US Constitutionalism. In: Cambridge University Press.

Grote, R. (2001). Rule of Law, Rechtsstaat, /y Etat de Droit. PensamientoConstitucional, 8(8), 127 176.

Habermas, J. (2015). Between facts and norms: Contributions to a discourse theory of law and democracy: John Wiley \& Sons.

Hutchinson, A. C. (1987). Democracy and the Rule of Law.

Jain, M. P. (2003). Indian constitutional law: Wadhwa \& Company.

Karpen, U. Good Governance through Transparent Application of the Rule of Law' (2009). European Journal of Law Reform, 11, 213. 
Kavanagh, A. (2009). Constitutional Review under the UK Human Rights Act: Cambridge University Press.

Kommers, D. P. (2006). The Federal Constitutional Court: Guardian of German Democracy. The Annals of the American Academy of Political and Social Science, 603(1), 111-128. doi:10.1177/0002716205283080

Kommers, D. P., \& Miller, R. A. (2012). The Constitutional Jurisprudence of the Federal Republic of Germany: Revised and Expanded: Duke University Press.

Kumm, M. (2009). Democracy is not enough: Rights, proportionality, and the point of judicial review.

Macfarlane, L. J. (1985). The theory and practice of human rights: Temple Smith.

Mhone, G., \& Edigheji, O. (2003). Globalization and the challenges of governance in the new South Africa: Introduction. Governance in the New South Africa: The Challenges of Globalisation.

Møller, J., \& Skaaning, S.-E. (2012). Systematizing thin and thick conceptions of the rule of law. Justice System Journal, 33(2), 136-153.

Möller, K. (2009). Two conceptions of positive liberty: towards an autonomy-based theory of constitutional rights. Oxford Journal of Legal Studies, 29(4), 757-786.

Mureinik, E. (1994). A bridge to where? Introducing the Interim Bill of Rights. South African Journal on Human Rights, 10(1), 31-48.

Neumann, F. (2014). The change in the function of law in modern society. RevistaBrasileiraEstudos Politicos, 109, 13.

Ovey, C., \& White, R. (2003). European Convention on Human Rights. NORTHERN IRELAND LEGAL QUARTERLY, 54(3), 336-338.

Perry, M. J. (2003). Protecting human rights in a democracy: what role for the courts. Wake Forest L. Rev., 38, 635.

Pulido, C. B. (2013). The migration of proportionality across Europe. NZJPIL, 11, 483.

Raz, J. (2017). The rule of law and its virtue. In The Rule of Law and the Separation of Powers (pp. 77-94): Routledge.

Rehg, W., \& Bohman, J. (1996). Discourse and democracy: the formal and informal bases of legitimacy in Habermas' Faktizität und Geltung. Journal of Political Philosophy, 4(1), 79-99.

Rehman, M. H. U., Gilani, S. R. S., \& Khan, M. A. S. (2021). Contextual Analyses of "The Doctrine of a Margin of Appreciation" in the Frameworks of the European Court of Human Rights and the British Legal System. Journal of European Studies (JES), 37(1), 1-14.

Reynolds, N. B. (1989). Grounding the rule of law. Ratio Juris, 2(1), 1-16.

Roux, T. (2008). Principle and pragmatism on the Constitutional Court of South Africa. International journal of constitutional law, 7(1), 106-138.

Slapper, G., \& Kelly, D. (2011). The English Legal System: 2011-2012: Routledge.

Tamanaha, B. Z. (2004). On the rule of law: History, politics, theory: Cambridge University Press.

Weinrib, L. E. (2001). The Supreme Court of Canada in the age of rights: constitutional democracy, the rule of law and fundamental rights under Canada's constitution. Can. B. Rev., 80, 699.

Wicks, E. (2003). The greater good issues of proportionality and democracy in the doctrine of necessity as applied in re a. Common Law World Review, 32(1), 15-34 